\title{
SUSTAINABLE DEVELOPMENT OF THE ROMANIAN RURAL AREAS
}

\author{
Professor PhD Burja Vasile, "1 Decembrie 1918” University of Alba Iulia, \\ e-mail:vasile_burja@yahoo.com \\ Eng. Morariu Carmen, County Office for Rural Development and Fishing Payments \\ Eng. Rusu Otilia, County Office for Rural Development and Fishing Payments
}

\begin{abstract}
The problem of the sustainable development of the rural areas constitutes a high priority for Romania in the quality of European Union's member state. This supposes adopting of a coherent strategy that can realize a balance between the preservation demand of the economic, ecologic and socio-cultural area on one hand, and the tendency of life country modernization, on the other side. In the paper are evidenced some aspects, projects and action directions concerning the sustainable development of the Romanian rural space.
\end{abstract}

Key words: rural area, sustainable development, strategies, sustainable agriculture

JEL Codes: R0, Q18

\section{Introduction}

The economic, social, political and ecological dimensions of the rural environment are complex and have multiple implications, starting with theoretical and practical reasons. The process of urbanization that takes place at world-wide level has become one of the global problems of mankind, because of the disparities created between the countryside and the city, which are materialized in the cultural, economical and social aspects that are synthesized in the terms of urban and rural civilizations, which define the different realities of the geographical space.

On the other hand, there have been deep changes in the rural area, therefore the traditional image of the village with its specific cultural array is going through a profound transformation, tied to the contemporary technical progress which firstly influences the rural economy, but also the elements of comfort, civilization, cultural traditions, education, spiritual life, etc., in the rural world.

The practical implications of the rural space notion are related to the legal elements, to the strategic and operative actions tied to the implementation of the regional development policies, which imply the preferential use of resources in order to achieve the economical-social cohesion and other priority objectives of the European Union.

The stipulations of the European Council regulation no. 1296/1994 regarding the European Charter for Rural Areas define this notion as being determined by those areas that belong to townships and outer-urban regions where the economic activities that take place are related to the vegetal and animal agricultural production, forestry production, fishing and water-crops, the industrial processing of the agricultural, forestry, fishy, and water-crops products, as well as handycraft and small industries activities, and rural tourism and recreation services. This definition of the rural area takes into account the occupational identity of its population, to which is necessary to add the cultural identity and the identity tied to the specific social relations.

According to the reasons mentioned before, the complex approach of the rural area offers the possibility to identify the specific functions performed by the rural space, such as: 
- the economic function - has as a main objective the production of agricultural products and other goods from the productive branches of upstream and downstream the agriculture, as well forestry, handy-craft, etc;

- the social-cultural function - keeps in sight the preservation and development of traditions, customs, cultural creations and social relationships specific to the rural area;

- the ecological function - pursues the achievement of a sustainable development, in full accordance with the elements of the natural environment.

From the perspective of the EU directives and community regulations, as well as the strategies and the national regional programs, thenceforth we'll display the present features and action direction towards a sustainable development of the rural region in Romania.

\section{The current features of the rural region in Romania}

According to the national legislation, the Romanian rural area covers $87.1 \%$ of the territory and $45.1 \%$ of the population. Considering that Romania counts for $6 \%$ of the European Union's surface, and the population makes up for $4 \%$ of the EU's population, we can assess the major development potential the Romanian rural space has in the national and international context.

According to the data supplied by the National Institute of Statistics [7] for the year 2007, the agriculture's contribution to the Gross Domestic Product (GDP) was 6.6\% and although the population working in agriculture has dropped, it still holds a high weigh of $29.5 \%$, but the number of employees in this branch of the economy doesn't exceed 3\%. From the active population's total, about $45 \%$ comes from the rural area, which shows the human resources potential the rural region has. The unemployment rate in the rural environment was $4.9 \%$, under the average of the national economy, which was $6.4 \%$, but those numbers don't include the disguised unemployment that is more acute in the rural region.

The rural population has a continuous diminution tendency because of the aging process which leads to a negative natural increase of population, to which the international migration is added. The internal migration rate from the urban to the rural is positive for the last the years, but it can't compensate for the down-fall caused by the two tendencies and is representative for the population over 45 years old, the younger population being attracted towards urban areas. The stabilization of the population in the rural region is one of the fundamental problems of the sustainable development.

The majority of the active population in the rural area $(64.2 \%)$ works in agriculture where low productivity is recorded, and as a result the incomes are lower than in the urban. The income per capita in the rural for the year 2003 was only $77.6 \%$ from the income per capita in the urban, and the gap is continuously growing. Agriculture represents the main income source in the rural area (it owns over $40 \%$ of the total incomes), but the incomes from the farmers' housework are regularly lower that the ones recorded in the rural households that also have incomes from salaries, obtained by doing other activities. In order to have a sustainable development, diversifying the activities that bring incomes is a problem that must be solved.

As a result of the low incomes, the poverty rate in the rural region $(22.3 \%$ in 2006$)$ is three times higher than the rate in the urban area (6.8\%). The most vulnerable persons to poverty are the ones who work in agriculture on their own, their poverty rate being $22 \%$ [4].

The education level of the population in the rural area is lower than the urban population's. This is a factor that attracts towards cities young families who want to ensure a future for their children through a more performing education.

Regarding the economic activities run in the rural environment, of course agriculture stays the main occupation of the inhabitants. Although Romania has a high agricultural potential, the agriculture remains a non-performing sector because of its organization manner, tied especially to the structure of the rural fund, developed after the privatization process. In 2005, from the total of 
4.256.152 agricultural holdings, 4.237 .889 were individual agricultural holdings $(99.6 \%)$ and only 18.263 were units with legal status $(0.4 \%)$. The individual agricultural holdings use an area of approximately 2.2 ha, and the medium size of the areas used by the units with a legal status is 269.2 ha [8].

Considering the average size of the used areas by the individual agricultural holdings, which are usually plotted (an average of 3.7 ha/holding), is practically impossible to implement efficient agricultural technologies. That's why in Romania most agricultural holdings practice sustenance agriculture, which is non-competitive and unsuited to the market conditions. In the European Union the average size of a farm is 12 ha and in the Czech Republic is 80 ha [6].

The agricultural production is vulnerable to the natural conditions and especially to drought. The farm equipments owned by individual agricultural holdings are insufficient and outperforming. The population which works in sustenance agricultural holdings is generally old and its technological knowledge is empirical.

The sustenance agricultural holdings maintain the general agricultural efficiency to a low level and will have to cover a restructuring process that especially targets the improvement of the land structures, which will lead to viable exploitations. This can be achieved through specific actions of agglomerating the land, such as: selling-buying, lease, associations, land swopping [1].

The agro-food industry is one of the main ways to capitalize the agricultural products. The development of this industry as closer as possible to the place where the products are obtained is necessary for improving the economic efficiency and the diversifying of the economic activities within the rural region. Although the production capacity of the agro-food industry in Romania is relatively developed, it still confronts with many problems tied to obeying to the EU standards regarding food safety and the quality of the production. The rational use of the production capacities and their optimum dimensioning, the adequate technical endowment and the supply with raw materials are problems which must be solved in order to increase the enterprises' competitiveness. The production of traditional products constitutes also an opportunity for the economic growth in the sectors of dairies, meat, bread manufacture and drinking products.

The forests in Romania represent an important economic potential for the development of the rural region. They count for an area of 6.7 million hectares, wherefrom $35 \%$ is privately owned. The pass-on of the forests has created new problems for the sustainable development of the forests' area, because of the excessive fragmentation and the small sizes of the exploitations. The illegal chopping of trees is one of the most serious threats for the Romanian forests.

Measures for the rational administration of the sylvan funds are imposed in order to turn the Romanian forests into an important factor for the superior capitalization of the rural area, the development and the modernization of the wood processing sector in competitive production units, which will turn into account the traditions of the work force.

An important spot within the rural economy is taken by the handy-craft activities and services. However, these activities are still poorly developed, although there is a potential which could contribute to improving the quality of life and to increasing the attractiveness of the rural area.

The rural tourism and agro tourism represent activities that generate alternative incomes in the rural area, which can be developed by taking into account the natural and ethnographic potentials, the folkloric traditions, the agricultural practices and the architecture specific to the Romanian countryside, as well as the hospitality. In Romania this form of tourism has been developed in areas with a special natural potential and around sightseeing spots in order to add to the accommodation offer. Another important potential for the tourism practiced in weekends is represented by the rural areas outside cities. Although the number of agro-boarding-houses has grown from 343 in the year 2001 to 1753 in 2007, the tourism infrastructure still doesn't cover the demands of the tourists from the quantity and the quality point of views. 
Despite all the efforts put into accessing European pre-joining and structural funds, the transport infrastructure is still poorly developed in the rural region.

The length of the roads in counties and townships was $63970 \mathrm{~km}$ in 2005 , which represents about $80 \%$ from the total. Only $6774 \mathrm{~km}$ (about 10.6\%) from the counties and townships roads were modernized. [8]

The public infrastructure which ensures the water, sewage and marsh gas supplies is still very rare in the rural area. In 2005 from a total of 2851 townships, only $742(26 \%)$ were connected to the natural gases, $1620(56.8 \%)$ had running water and $693(24.3 \%)$ had sewages. Not all the villages that are a part of those townships have the mentioned utilities [8].

The natural environment, the airy landscape, the flora and fauna specific for the rural area represent its irresistible attraction and a priceless treasury for humanity [2]. The natural resources are well preserved, the variety of the traditional landscapes and the biological diversity are the main characteristics of the rural environment in Romania. Practicing an industrial agriculture has had negative effects on the environment, so much so that by the year 1990 the activity production, especially of the big enterprises that were owned by the state, has generated different types of pollution: soil pollution, especially by using synthesis chemical substances for plant-health treatments, the artificial fertilization of soils, slopping vegetal and animal residuals; the air pollution through treatments applied to crops; water pollution, etc. The abandonment of arable areas after 1990, narrowing the pasturage, the lack of land improvements have led to soil erosion, the degradation of meadows and of the landscape and other phenomena with negative consequences on the environment.

The cultural and spiritual life of the habitants in Romanian villages is an important segment of the rural space's European treasury because of its richness and authenticity. Traditions, customs tied to different family events or religious celebrations, art and other folkloric creations constitute elements that round up the real dimension of the rural area. The Romanian rural space includes many atrophic spots that have a patrimonial value, such as: archaeological sites, historic centres, churches, memorial houses, museums, libraries, community centres, buildings with an architectural value, etc.

Towards the mentioned realities of the rural region a new approach is being imposed regarding the policies meant to sustainably develop it and to turn to advantage the economic, social, cultural and environmental aspects of the Romanian village.

\section{Directions for the sustainable development of the rural region}

The sustainable development of the rural area can't be done at chance. It constitutes an important element of the National Sustainable Development Strategy in Romania, which is conceived on the basis of the goals in the Sustainable Development Strategy of the European Union adopted in 2001 at Goteborg by the European Council, and the objectives of the Lisbon Strategy in 2000 , which targeted the transformation of the EU in the "most dynamic and competitive economy of the world".

Accessing community funds is conditioned by the elaboration of programming documents by the state members that define the sectors towards which the financial assistance of the EU will be directed [5]. The Romanian government has elaborated through the Agriculture, Forestry and Rural Development Ministry two programming documents which orient the main guiding marks of the rural development for 2007-2013, such as: the National Strategy Plan for Rural Development [10] and National Rural Development Programme [9].

The national strategy plan for rural development has the following objectives:

- increasing the economic dynamism of the rural areas in Romania, including the sustainable development of the agrarian and forestry sectors;

- preserving and improving the natural environment; 
- $\quad$ rising the social dynamism and the quality of life in the rural areas.

According to the mentioned programming documents, the priorities for the rural development in Romania are structured on four fundamental directions (axes).

Axis 1 targets the improvement of the competitiveness in agriculture and forestry. Three strategic objectives will be implemented in order to achieve this, they regard improving the human resources and the technical capital used in agriculture and forestry, but also for the development of the processing-commercializing activities for the obtain products.

Improving the farmers' competencies and the competencies of the people who work in agriculture and forestry will allow the producers to perfect the management of the holdings on criteria of economic efficiency, as well as the evolution of activities comparable to the environment (including practicing green agriculture and the use of alternative energies).

Increasing the competitiveness of commercial and sustenance farms takes into account the investments directed towards technical progress, which will contribute to cutting down costs, to complying with the European standards of hygiene and labour protection, to creating and modernizing the infrastructure necessary for agricultural and forestry holdings.

The restructuring and the modernization of the processing and commercialization sectors for agricultural and forestry products require investments in order to process and market these products, which will result in increasing the value added to the products and in complying with the quantitative, qualitative and food safety norms. This objective will generate new work places in the rural area and will lead to the growth of the family income.

The measures in Axis 2 are orientated towards improving the environment and the countryside by ensuring the continuous use of agricultural lands, preserving and improving the natural resources and habitats, promoting sustainable development for the forestry lands. Achieving the strategic objectives of this axis will lead to avoiding the abandonment of lands in depressed areas, the possibility to implement codes of good practice in agriculture, which will ensure the environment protection and the improvement of the soil's, water's and air's biodiversity, as well as the expansion of forestry areas, with all the positive consequences of this action.

The objectives in Axis 3 regard the quality of life's improvement in the rural region and the diversification of the rural economy. Improving the economic performances of the agricultural holdings will implicitly lead to the growth of the work productivity, which will generate an excess in the work force. In order to settle down this work force in the rural area, it's necessary to diversify the non-agricultural activities, such as: processing own raw materials and direct commercialization, encouraging agro-tourism activities and handy-craft activities.

Increasing the attractiveness of the rural areas implies the improvement of the local and touristic infrastructure, the protection of the cultural heritage, the development of socio-economic services for the population.

The rural development objectives can't be conceived and implemented without the decisive input of the local community, that's why it's natural for the strategy of rural development to have as a goal the development of the abilities and the awareness stimulation in local actors regarding the importance of local governing. The involvement of local actors in the organization and governing of the territory can't be efficient without knowledge and competencies that are able to identify opportunities, set priorities and capitalize the resources of the rural region.

Axis 4 refers to the implementation of the LEADER approach, which implies the elaboration and implementation of local development strategies that will capitalize the endogenous potential of the territories and improve local governing. Facilitating and promoting cooperation partnerships in rural areas in order to accomplish sustainable development through the active integration of the population, institutions and business environment are encouraged by the measures of this axis.

Putting into practice the rural development strategy implies adequate financial resources. These resources can come from local budgets, budgetary grants and structural funds. The total 
expenses for implementing the National Rural Development Plan are estimated at 13.4 billion Euros, from which approximately 10 billion Euros represent public expenses and 3.4 represent private expenses. Only the Agricultural Fund for Rural Development (EAFRD) will allot 8.022 billion Euros for achieving the objectives of the four Axes.

\section{Conclusions}

The analysis presented in the previous chapters has emphasized the socio-economic, natural and cultural potentials of the Romanian space, its current features and the future development directions. The sustainable development of the rural region is a present and future option of the rural policy that seeks its preservation and improvement, the growth of the economic competitiveness and the quality of life's improvement.

Joining the European Union has put on the line for our country new challenges and objectives. One of these objectives is the sustainable development of the rural region and it constitutes a priority for the agricultural policies. This objective can be achieved by defining a few political options and adequate strategies that will meet the consensus of the involved authorities, economic agents and population.

Turning into account the human, natural and cultural resources and the implicated technical capital synthesizes the road to a sustainable development of the rural region.

\section{References:}

1. Burja C., Burja V.- Performanța economică a exploatațiilor agricole în sistemul dezvoltării durabile, Editura Casa cărții de ştiință, Cluj-Napoca, 2008

2. Otiman P.I. - Viața rurală românească pe lungul drum între Flămânzi şi Uniunea Europeană, Editura Academiei Române, Bucureşti, 2007

3. Zoltán S. - Spațiul rural românesc intre identitate şi globalizare), www.historycluj.ro/SU/cercet/Salanki/SpatiuRural.htm

4. BM, MMFES, INS,- România: Raport de evaluare a sărăciei , $\mathrm{http}: / /$ siteresources.worldbank.org

5. EU - Council Regulation (EC) No 1698/2005 of 20 September 2005 on support for rural development by the European Agricultural Fund for Rural Development (EAFRD), http://eufinantare.info/regulamente/1698_ro.html

6. EU, Directorate General for Agriculture and Rural Development - Rural development in the European Union statistical and economic information, Report 2007., http://ec.europa.eu/agriculture/agrista/rurdev2007/index_en.htm

7. INS - România în cifre, 2008, www.insse.ro

8. INS - Statistics Yearbook, 2006

9. MARD - National Rural Development Programme 2007-2013, www.maap.ro

10. MARD - National Strategy Plan for Rural Development, 2007-201, www.maap.ro 